CLINICAL STUDY

\title{
Thyroid hormone receptors are down-regulated in skeletal muscle of patients with non-thyroidal illness syndrome secondary to non-septic shock
}

\author{
$\mathrm{J} \mathrm{Lado-Abeal}^{1,2,3}$, A Romero ${ }^{3}$, I Castro-Piedras ${ }^{1,3}$, A Rodriguez-Perez ${ }^{4,5}$ and J Alvarez-Escudero ${ }^{4,5}$ \\ ${ }^{1}$ Division of Endocrinology, Department of Internal Medicine and ${ }^{2}$ Department of Cell Biology and Biochemistry, School of Medicine, Texas Tech University \\ Health Sciences Center, 3601 4th Street, STOP 9410, Lubbock, Texas 79430-9410, USA, ${ }^{3}$ UETeM, Department of Medicine, School of Medicine, \\ University of Santiago de Compostela, Rua San francisco s/n, 15782 Santiago de Compostela, Spain, ${ }^{4}$ Service of Anaesthesiology and Reanimation, \\ Department of Surgery, Complejo Hospitalario Universitary de Santiago de Compostela, SERGAS Travesia da Choupana s/n, 15706 Santiago de \\ Compostela, Spain and ${ }^{5}$ School of Medicine, University of Santiago de Compostela, Rua San francisco s/n, 15782 Santiago de Compostela, Spain \\ (Correspondence should be addressed to J Lado-Abeal; Email: joaquin.lado@ttuhsc.edu)
}

\begin{abstract}
Aim: Non-thyroidal illness syndrome (NTIS) is related to changes in thyroid hormone (TH) physiology. Skeletal muscle (SM) plays a major role in metabolism, and TH regulates SM phenotype and metabolism. We aimed to characterize the SM of non-septic shock NTIS patients in terms of: i) expression of genes and proteins involved in TH metabolism and actions; and ii) NFKB's pathway activation, a responsible factor for some of the phenotypic changes in NTIS. We also investigated whether the patient's serum can induce in vitro the effects observed in vivo.

Methods: Serum samples and SM biopsies from 14 patients with non-septic shock NTIS and 11 controls. Gene and protein expression and NFKB1 activation were analyzed by quantitative PCR and immunoblotting. Human SM cell (HSkMC) cultures to investigate the effects of patient's serum on TH action mediators.

Results: Patients with non-septic shock NTIS showed higher levels of pro-inflammatory cytokines than controls. Expression of TR $\beta$ (THRB), TR $\alpha 1$ (THRA), and retinoid X receptor $\gamma$ (RXRG) was decreased in NTIS patients. RXRA gene expression was higher, but its protein was lower in NTIS than controls, suggesting the existence of a post-transcriptional mechanism that down-regulates protein levels. NFKB1 pathway activation was not different between NTIS and control patients. HSkMC incubated with patient's serum increased TH receptor and RXRG gene expression after $48 \mathrm{~h}$.

Conclusions: Patients with non-septic shock NTIS showed decreased expression of TH receptors and RXRs, which were not related to increased activation of the NFKB1 pathway. These findings could not be replicated in cultures of HSkMCs incubated in the patient's serum.
\end{abstract}

European Journal of Endocrinology 163 765-773

\section{Introduction}

Non-thyroidal illness syndrome (NTIS) forms a part of the neuroendocrine response to metabolic stress (1), and is characterized by a low 3,5,3'-triiodothyronine $\left(\mathrm{T}_{3}\right)$ and normal-high $3,3^{\prime}, 5^{\prime}$-triiodothyronine (reverse of $\mathrm{T}_{3}, \mathrm{rT}_{3}$ ) in serum and tissues, normal or low serum thyroxine $\left(\mathrm{T}_{4}\right)$, and inappropriately normal or low serum TSH in relation to serum levels of $\mathrm{T}_{4}$ and $\mathrm{T}_{3}$ (2). Whether NTIS is a beneficial adaptive response to reduce energy consumption, or a form of secondary hypothyroidism that requires thyroid hormone $(\mathrm{TH})$ treatment is controversial (3-6).

The inappropriately normal or low serum TSH levels in NTIS patients are due to an impairment of hypothalamic-pituitary function $(7,8)$, a situation where TH replacement could be beneficial. However, the molecular changes observed in some peripheral tissues from patients with NTIS seem to be directed at decreasing $\mathrm{TH}$ action. In humans, $\mathrm{T}_{3}$ is mainly produced by extrathyroidal enzymatic deiodination of $\mathrm{T}_{4}$, mainly in the liver and skeletal muscle (SM) (9). Low $\mathrm{T}_{3}$ and elevated $\mathrm{rT}_{3}$ levels observed in NTIS patients are related to a decrease in liver type 1 iodothyronine deiodinase (DIO1) and SM type 2 iodothyronine deiodinase (DIO2) activities, and to an increase in type 3 iodothyronine deiodinase (DIO3) activity in the liver and SM (9-11). Patients with fatal NTIS have decreased $\mathrm{T}_{4}$ and $\mathrm{T}_{3}$ in most tissues $(12,13)$ caused in part by reduced tissue uptake, although TH bioavailability is 
not limited if appropriate replacement therapy is given (2). A decrease in mRNA expression of the TH receptors such as TH receptor $\alpha$ (THRA) and TH receptor $\beta$ $(T H R B)$ and their nuclear partner retinoid $X$ receptor $\gamma$ $(R X R G)$ has been reported in SM and subcutaneous adipose tissue of patients with NTIS caused by septic shock (11). The functional consequences of decreased TH receptors and RXRG expression remain unknown, but $a$ priori these findings suggest that $\mathrm{TH}$ replacement might be less effective in NTIS patients than in patients with hypothyroidism.

Many of the molecular mechanisms responsible for the above-described changes remain to be characterized. Increased levels of pro-inflammatory cytokines, endogenous glucocorticoids, and glucagon, typically seen in critically ill patients, together with the administration of glucocorticoids and dopaminergic drugs, could directly suppress TRH secretion, the pituitary response to TRH, and TSH secretion $(7,8$, 14). Patients with NTIS have altered TSH glycosylation, which is associated with reduced biological activity (15), and lethal NTIS is associated with major morphological changes in the thyroid gland, including loss of colloid and reductions in follicular size and thyroid weight (16). Cytokines affect thyroid cell function in several ways $(14,17)$, including a decrease in basal and TSH-stimulated iodide uptake due to interleukin 1 (IL1) and tumor necrosis factor- $\alpha$ (TNF- $\alpha$ ), inhibition of thyroglobulin synthesis by IL1, TNF- $\alpha$ (TNF), and interferon- $\gamma$ (IFN- $\gamma$ ), a decrease in thyroperoxidase expression by IL1, IL6, and IFN- $\alpha$ (IFNA1), and a decrease in $\mathrm{T}_{3}$ secretion by IL1, TNF- $\alpha$ and IFN- $\gamma$ (IFNG).

Nuclear factor of kappa light chain enhancer of activated B cells (NFKB) is a family of transcription factors that plays a pivotal role in immune and inflammatory responses. Activated NFKB1 is a potential molecular factor at the root of NTIS in patients with septic shock and increased serum cytokines level (18); in vitro studies using HepG2 cells have shown that NFKB1 activation attenuates the induction of DIO1 by $\mathrm{T}_{3}$ (18), and that the decrease in DIO1 mRNA expression induced by IL1 $\beta$ (IL1B) is mediated by the simultaneous activation of NFKB1 and AP-1 pathways (19).

$\mathrm{SM}$ is a major contributor to resting metabolic rate and plays a crucial role in protein metabolism (20). TH controls expression of more than $50 \%$ of SM genes (21) and, together with neuronal activity and physical exercise, regulates the cytoarchitecture and metabolic characteristics of SM. TH stimulates the development of fast muscle fiber characteristics in SM: $\mathrm{T}_{3}$ induces a shift from myosin heavy chain 1 (MYH1), mainly expressed in slow oxidative muscle fibers, to MYH4, typically expressed in the fast glycolytic muscle fibers (22). $\mathrm{T}_{3}$ also regulates $\mathrm{Ca}^{2+}$ cycling by the sarcoplasmic reticulum (SR), a source of heat generation; expression of SERCA1 (ATP2A1), a SR $\mathrm{Ca}^{2+}$-ATPase predominantly expressed in fast muscle fibers, is increased by $\mathrm{T}_{3}$ in slow muscle fibers simultaneously with the shift from MYH1 to MYH4 in these fibers (23). $\mathrm{T}_{3}$, through genomic and non-genomic actions, increases lipid oxidation and glycolysis in SM (24), although overall ATP production remains constant since TH increases energy uncoupling and expenditure. Finally, TH increases protein breakdown and the efflux of branched chain amino acids from the muscle (25).

Injurious stimuli increase adipose tissue lipolysis that increases availability of fatty acids to different tissues as a source of energy (26). Peroxisome proliferator-activated receptor $\gamma$ (PPARG) plays a central role in lipid and glucose metabolism and is important for maintaining insulin sensitivity. PPARG expression is positively regulated by $\mathrm{T}_{3}(27)$, and it forms heterodimers with RXRs, nuclear receptor co-repressor 1 (NCOR1), and NCOR2 (NCOR2 or SMRT) (28), competing with TH receptors for these proteins. In mice, lipopolysaccharides (LPS) cause a decrease in expression levels of TH receptors and PPARG in several tissues (26), and several members of the multiprotein complex that regulate the transcriptional activity of PPARG are affected during NTIS (11). However, the changes and involvement of PPARG in human NTIS remain unknown.

To gain further insights into human NTIS pathophysiology, we investigated some of the molecular changes related to TH metabolism and actions in SM samples from a group of patients with NTIS admitted into an intensive care unit (ICU) for non-septic shock. Specifically, we quantified the following: i) mRNA expression of TH transporter monocarboxylate transporter 8 (MCT8 or SLC16A2), DIO2, THRA, THRB1, RXRA, RXRB, RXRG, PPARG, NCOR1, NCOR2, and nuclear receptor co-activator 1 (NCOA1), glucocorticoid receptor $\alpha$, nuclear receptor subfamily 3 , group $C$, member 1 (NR3C1 or GCR), and the TH-responsive genes, solute carrier family 2, member 4 (GLUT4 or SLC2A4), uncoupling protein 3 (UCP3), lipoprotein lipase (LPL), the MYH genes MYH1 SM adult (MYH1) and MYH4 SM (MYH4 or MyHC-IIb), and the SR calcium ATPases ATPase $\mathrm{Ca}++$ transporting, cardiac muscle, fast twitch 1 (ATP2A1 or SERCA1) and ATPase Ca ++ transporting, cardiac muscle, slow twitch 2 (ATP2A2 or SERCA2); ii) protein expression levels of THRA, THRB1, RXRG, RXRB, and PPARG; and iii) mRNA expression of nuclear factor NF-kappa-B p50 subunit (nuclear factor of kappa light polypeptide gene enhancer in B cells 1 or NFKB1) and $p 65$ (v-rel reticuloendotheliosis viral oncogene homolog A (avian) or RELA), together with activation of the NFKB1 pathway. Finally, we sought to determine whether the changes observed in mRNA expression of MCT8, THRA, THRB1, and RXRG in SM in vivo could be reproduced in vitro by incubating cells from a human SM cell line (HSkMC) in serum from patients with NTIS.

Our results showed that patients with non-septic shock NTIS have a decreased expression of TH receptors in the SM, which is not mediated by an activation of the NFKB1 pathway. 


\section{Materials and methods}

\section{Subjects}

The study was conducted on two groups of patients with no previous history of thyroid disease. The control group comprised 11 patients ( 7 males and 4 females), median age 62 years (range 37-77), selected from among those referred to our hospital for knee or hip replacement. The non-septic NTIS group comprised 14 ICU patients (11 males and 3 females), median age 57 years (range 45-89), hospitalized for multiple traumatic injuries $(n=4)$, intracranial hemorrhage $(n=8)$, cardiac arrest during hemodialysis $(n=1)$, and food asphyxia $(n=1)$. NTIS patients were transferred to ICU for ventilatory and circulatory support. Low-medium dosage of noradrenaline was administered to six patients. Sedation and analgesia were maintained by continuous i.v. infusion of propofol and morphine, and nutrients were given by continuous total parenteral nutrition. Eight patients $(57.14 \%)$ recovered after a median stay in ICU of 5.37 days (range 1-11 days), and six patients (42.86) died in ICU.

SM biopsies were obtained from the vastus lateralis muscle as previously described (11). The biopsies were obtained during surgery in control patients and in the first $48 \mathrm{~h}$ after ICU admission in NTIS patients.

In all cases, informed consent was obtained from the control patients or the closest family member of the ICU patients. The study protocol was approved by the Ethical Review Board of the Medical School of the University of Santiago de Compostela.

\section{Serum analysis}

Blood samples were obtained immediately before surgery in the control group and before the muscle biopsy in the non-septic NTIS group. Chemiluminescence was used to measure serum TSH (normal 0.41-4.94 mU/l), free $\mathrm{T}_{4}\left(\mathrm{FT}_{4}\right.$, normal $0.85-$ $1.60 \mathrm{ng} / \mathrm{dl}, 10.94-21.75 \mathrm{pmol} / \mathrm{l})$, free $\mathrm{T}_{3}\left(\mathrm{FT}_{3}\right.$, normal 2.53-4.29 pg/ml, 0.039-0.066 pmol/l) (ADVIA Centaur, Bayer Diagnostics), total cortisol $(\mu \mathrm{g} / \mathrm{dl})$, TNF- $\alpha$ (ng/l), IL2 receptor (IL2R, U/ml), IL6 (ng/l), and IL8 (ng/l) (Immulite 2000, DPC, Gwynedd, UK). rT 3 (normal $0.15-0.35 \mathrm{ng} / \mathrm{ml}, 0.23-0.54 \mathrm{nmol} / \mathrm{l}$ ) was measured by RIA (Biocode Hycel, Massy, France). Thyroperoxidase antibodies (TPOAb) and thyroglobulin antibodies $(\mathrm{TgAb})$ were measured by an ELISA (Orgentec Diagnostika, Mainz, Germany).

\section{HSkMCs culture for in vitro studies}

Primary HSkMCs (ScienCell Research Laboratories, San Diego, CA, USA) were incubated in 12-well plates using media recommended by the manufacturer. At 80-90\% of confluence, growth medium was changed for a basal medium of DMEM plus $20 \%$ of a pool of human serum from control subjects or non-septic NTIS patients supplemented with gentamicin $(50 \mu \mathrm{g} / \mathrm{ml})$. Incubation was stopped at $0,6,12,24,48$, and $72 \mathrm{~h}$, and cells were harvested for RNA extraction and quantification of gene expression as described below.

\section{Total RNA isolation and real-time quantitative PCR}

Total RNA from SM biopsies and HSkMC cell cultures was extracted from TRIzol reagent (Invitrogen) according to the manufacturer's instructions. cDNA synthesis was generated from $1 \mu \mathrm{g}$ of total RNA using $5 \mu \mathrm{M}$ random hexamers, $2 \mathrm{mM}$ deoxynucleotides (Ecogen, Madrid, Spain), and M-MLV reverse transcriptase (Invitrogen).

Gene expression changes were quantified by quantitative PCR (QPCR). mRNA expression of MCT8, THRA, THRB1, and RXRG was evaluated in both SM biopsies and HSkMC cells; mRNA expression of DIO2, RXRA, RXRB, PPARG, SRC1, NCOR1, SMART, NCOA1, GLUT4, UCP3, LPL, NR3C1, MYH1, MYH4, SERCA1, SERCA2, NFKB1, and RELA was measured in SM biopsies. QPCRs were performed in a LightCycler 2.0 (Roche) using specific probes and oligonucleotide primers designed by Universal ProbeLibrary (Roche) as previously described (11). Gene expression was normalized to RNA polymerase II following the $2^{-\Delta \Delta C_{t}}$ method (29).

\section{Immunoblotting}

Owing to the limited amount of SM tissue available from biopsies and the high protein concentration required for western blotting (25-75 $\mu \mathrm{g} /$ lane), total protein extracts were used instead of cytoplasm and nucleus protein. Total protein extraction was obtained after sonication of SM biopsies in $150 \mu \mathrm{l}$ RIPA buffer, $\mathrm{pH} 7.4$ (50 mM Tris$\mathrm{HCl}, \mathrm{pH} \mathrm{8,} 150 \mathrm{mM} \mathrm{NaCl}, 1 \% \mathrm{NP}-40,0.5 \%$ sodium deoxycholate, and $0.1 \%$ SDS), containing protein inhibitors (phenylmethylsulfonyl fluoride (PMSF), and sodium orthovanadate $\left(\mathrm{Na}_{3} \mathrm{VO}_{4}\right)$; each at $1 \mu \mathrm{M}$ final concentration). The lysate was centrifuged for $30 \mathrm{~min}$ at maximum speed $(16000 \boldsymbol{g})$, and the supernatant was collected. Protein was quantified using the Bradford method, and equal amounts of protein were run on an SDS-PAGE (10\% polyacrylamide gel). After electrophoresis, the proteins were transferred to a nitrocellulose membrane and blocked for at least $1 \mathrm{~h}$ with $5 \%$ dried milk powder in TBS. The membrane was then incubated overnight with the first antibodies (dilution 1:1000 in blocking solution) against THRB1 (Acris Antibodies, AntibodyBcn SL, Barcelona, Spain, SM5022), THRA (Santa Cruz, Heidelberg, Germany, sc-772), PPARG (Santa Cruz, sc-772), RXRG (Santa Cruz, sc-555), RXRA (Santa Cruz, sc-553), and $\beta$-tubulin (Sigma, T-5168). After three washes of $10 \mathrm{~min}$ each with $0.2 \%$ TBS Tween 20 (TBS-T), the membrane was incubated with the appropriate HPR-conjugated 
secondary antibody (Sigma). Proteins were detected using ECL (Amersham). Quantification was performed using AlphaEaseFC software and normalized with $\beta$-tubulin.

\section{NFKB1 pathway activation}

The status of activation of the NFKB1 pathway was determined by analysis of cytoplasmic IkB $\alpha$ (NFKB1A) phosphorylation. After homogenization in PBS, samples were centrifuged for $5 \mathrm{~min}$ at $500 \mathrm{~g}$ at $4{ }^{\circ} \mathrm{C}$ and resuspended in a sucrose buffer $(0.32 \mathrm{M}$ sucrose, $10 \mathrm{mM}$ Tris- $\mathrm{HCl}, \mathrm{pH} 8.0,3 \mathrm{mM} \mathrm{CaCl} 2,2 \mathrm{mM} \mathrm{MgOAc}$, $0.1 \mathrm{mM}$ EDTA, $0.5 \% \mathrm{NP}-40,1 \mathrm{mM}$ dithiothreitol, and $0.5 \mathrm{mM}$ PMSF); cytoplasmic fractions were recovered after centrifugation of the samples for $5 \mathrm{~min}$ at $500 \mathrm{~g}$ at $4{ }^{\circ} \mathrm{C}$ to precipitate the nuclei. Cytoplasmic samples (40 $\mu \mathrm{g}$ /lane) were run and transferred as described above, blocked for $1 \mathrm{~h}$ in TBS-T and 3\% BSA, and incubated overnight at $4{ }^{\circ} \mathrm{C}$ with the primary antibody (anti-IkB $\alpha$ Ab (pS32/pS36); Biomol International, Hamburg, Germany, Grupo Taper SA, Madrid, Spain, SA-412) diluted to 1:1000 in blocking solution; antiGAPDH (AbCam, Cambridge, MA, USA ref Ab9485) was used as a loading control. Membranes washing incubation with HPR-conjugated secondary antibody and quantification of proteins were performed as described above. Quantification was normalized with GAPDH.

To demonstrate the specificity of the phosphorylation site-specific antibody, a peptide competition experiment was performed using an $\mathrm{IkB} \alpha(\mathrm{pS} 32 / \mathrm{pS} 36)$ control peptide pair (Biomol International, SP-412).

\section{Statistical analysis}

Data were analyzed using SPSS 12.0 for Windows (SPSS, Chicago, IL, USA). Results are expressed as mean \pm s.D., median, and range. The groups were compared by Student's $t$-test or the Mann-Whitney non-parametric test, as appropriate.

\section{Results}

Age and body mass index (BMI) were not significantly different between non-septic NTIS and control patients (Table 1). Non-septic NTIS patients had significantly lower serum $\mathrm{TSH}$ and $\mathrm{FT}_{3}$, and higher $\mathrm{rT}_{3}$ levels than controls, while no differences were found in serum $\mathrm{FT}_{4}$ (Table 1). TNF- $\alpha$, IL6, IL8, and IL2R were all significantly higher in non-septic NTIS patients than in controls (Table 1). Although non-septic NTIS patients presented higher serum cortisol levels than controls, no statistically significant differences were observed. $\mathrm{TPOAb}$ and $\mathrm{TgAb}$ were negative in all patients.

\section{mRNA expression in SM biopsies}

In controls, SERCA and MYH1 genes showed the highest expression levels, and MCT8 and MYH4 genes showed the lowest expression levels (Fig. 1). Glucocorticoid receptor $\alpha$, NR3C1, RXRA, GLUT4, UCP3, and LPL genes were all highly expressed in SM (Fig. 1).

Non-septic NTIS patients had lower expression levels of THRB1, THRA, RXRG, and DIO2, but higher

Table 1 Anthropometric and biochemical data for the control and non-septic shock non-thyroidal illness syndrome (NTIS) patients.

\begin{tabular}{llll}
\hline & Control & NTIS & $P$ \\
\hline Age (years) & $61.33 \pm 6.26$ & $62.29 \pm 4.04$ & $\mathrm{NS}$ \\
$\mathrm{BMI}\left(\mathrm{kg} / \mathrm{m}^{2}\right)$ & $62(37-77)$ & $57(45-89)$ & $\mathrm{NS}$ \\
& $30.04 \pm 1.24$ & $27.57 \pm 0.90$ & \\
$\mathrm{TSH}(\mathrm{mU} / \mathrm{l})$ & $29.14(25.51-40.70)$ & $26.30(24.08-35.62)$ & $P<0.01$ \\
& $2.21 \pm 0.39$ & $0.90 \pm 0.32$ & $\mathrm{NS}$ \\
$\mathrm{FT}_{4}(\mathrm{ng} / \mathrm{dl})$ & $2.37(0.5-4.12)$ & $0.47(0.04-4.5)$ & \\
& $1.19 \pm 0.06$ & $1.22 \pm 0.11$ & $P<0.001$ \\
$\mathrm{FT}_{3}(\mathrm{pg} / \mathrm{ml})$ & $1.19(0.92-1.61)$ & $1.26(0.64-1.90)$ & \\
& $2.81 \pm 0.13$ & $1.84 \pm 0.09$ & $\mathrm{~N}<0.01$ \\
$\mathrm{rT}_{3}(\mathrm{ng} / \mathrm{ml})$ & $2.74(2.18-3.48)$ & $1.84(0.92-2.35)$ & \\
& $0.22 \pm 0.02$ & $0.69 \pm 0.17$ & $P<0.001$ \\
$\mathrm{Cortisol}(\mu \mathrm{g} / \mathrm{dl})$ & $0.22(0.12-0.33)$ & $0.49(0.19-2.36)$ & \\
& $15.50 \pm 2.27$ & $25.93 \pm 6.18$ & $P<0.001$ \\
$\mathrm{TNF}-\alpha(\mathrm{ng} / \mathrm{l})$ & $15(4-28)$ & $21.50(6-98)$ & \\
& $5.84 \pm 0.18$ & $27.1 \pm 5.94$ & \\
$\mathrm{IL} 6(\mathrm{ng} / \mathrm{l})$ & $5.8(5.4-6.25)$ & $22(12-70)$ & \\
& $4.70 \pm 0.82$ & $311 \pm 132$ & $P<0.001$ \\
$\mathrm{IL} 8(\mathrm{ng} / \mathrm{l})$ & $4.1(2.5-9.8)$ & $164(20-1277)$ & \\
& $11.56 \pm 1.31$ & $143.2 \pm 106.7$ & \\
$\mathrm{IL} 2 \mathrm{R}(\mathrm{U} / \mathrm{ml})$ & $11(7-17)$ & $25(9-993)$ & \\
& $440 \pm 44$ & $976(548-8022)$ &
\end{tabular}

Data are shown as mean \pm s.D. (upper), median, and range (lower). 


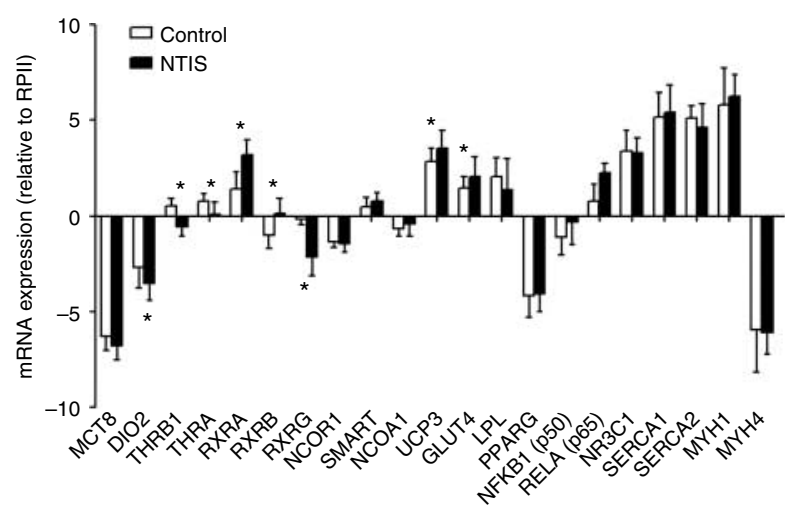

Figure 1 Relative mRNA gene expression in the skeletal muscle biopsies from control and non-septic shock NTIS patients. Gene expression is represented as the difference in expression between a reference gene, RNA polymerase II, and the genes of interest. In control biopsies, SERCA and MYH1 had the highest expression levels, and MCT8 and MYH4 had the lowest expression levels. NTIS patients had lower levels of THRA, THRB1, and RXRG, and higher levels of RXRA, UCP3, and GLUT4 gene expression than control patients. ${ }^{*} P<0.05$.

expression levels of RXRA, RXRB, UCP3, and GLUT4 than control patients (Fig. 1). No differences between NTIS and control patients were observed for MCT8, NCOR1, SMART, NCOA1, LPL, PPARG, NR3C1, MYH1, MYH4, SERCA1, or SERCA2 (Fig. 1).

\section{Protein expression in SM biopsies}

To evaluate whether changes in mRNA expression were accompanied by changes in protein levels, we analyzed the protein expression of THRA $(55 \mathrm{kDa})$, THRB1 (52-55 kDa), RXRG ( $51 \mathrm{kDa})$, RXRA (54 kDa), and PPARG (67 kDa) normalized with $\beta$-tubulin (50 kDa). Immunoblotting of RXRs showed the expected $51 \mathrm{kDa}$ (RXRG) and $54 \mathrm{kDa}$ (RXRA) weights (Fig. 2). A band that did not correspond to the size predicted was also observed, which could represent an alternative and unknown RXR isoform, reflecting the molecular complexity of RXRs. The THRB1 antibody turned out to be relatively unspecific, and only the band expected from the control test (nuclear protein extract from placenta) is shown (Fig. 2). THRB1, RXRG, and RXRA expression levels were significantly lower in non-septic NTIS patients than in control patients (Fig. 2); although THRA expression was lower in non-septic NTIS patients than in controls, statistical significance was not reached. No differences were observed in PPARG expression between the two groups (Fig. 2).

\section{Expression of $p 50$ and $p 65$ subunits and NFKB1 activation status in SM}

mRNA expression of NFKB1 (p50) and RELA (p65) was significantly elevated in non-septic NTIS patients versus controls (Fig. 3A).
IkB $\alpha$ immunoblotting showed two bands, a $40 \mathrm{kDa}$ product corresponding to phosphorylated IKB $\alpha$ and a $36 \mathrm{kDa}$ product that corresponds to non-phosphorylated $\operatorname{IKB} \alpha$ (Fig. 3B). No statistically significant differences were observed in $\operatorname{IkB} \alpha$ phosphorylation between non-septic NTIS and control patients.

\section{Effects of patient's serum on mRNA expression of MCT 8, THRB1, THRA, and RXRG in HSkMC cultures}

HSkMC cultured in serum from control patients showed a significant increase in mRNA expression of THRA, THRB1, and RXRG at 48 and $72 \mathrm{~h}$. By contrast, MCT8 expression increased at 6 and $12 \mathrm{~h}$, but at $24 \mathrm{~h}$, it had returned to basal expression levels with no further changes observed at 48 or $72 \mathrm{~h}$ (Fig. 4). HSkMC cultured in serum from NTIS patients showed a similar response, although the expression of THRB1 was higher at 48 and $72 \mathrm{~h}$ with respect to controls (Fig. 4).

\section{Discussion}

NTIS is caused by an impairment of hypothalamicpituitary function and of the physiological mechanisms producing $\mathrm{T}_{3}$ in peripheral tissues in response to moderate-severe illness and starvation. Depending on the severity of the noxious agent, extent of damage, and time taken to recover, several molecular changes affecting the transport, tissue uptake, metabolism, and action of THs can be observed (30). Although the molecular mechanisms responsible for NTIS remain speculative, the changes are tissue-specific (11).

SM has a crucial role in protein metabolism and contributes to the resting metabolic rate of the organism. Since TH regulates a large number of SM genes (21), we aimed to investigate some of the molecular changes in $\mathrm{TH}$ metabolism and action occurring in the SM of patients with NTIS. Previously, we have shown that SM from patients with NTIS

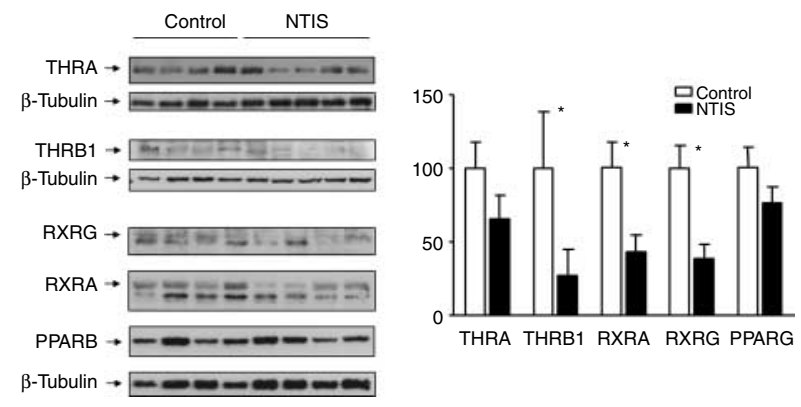

Figure 2 THRA, THRB1, RXRG, RXRA, and PPARG protein levels were evaluated by immunoblotting. All these proteins were decreased in SM samples from NTIS patients, although differences in THRA and PPARG were not statistically significant. ${ }^{*} P<0.05$, NS means non-specific. 
A
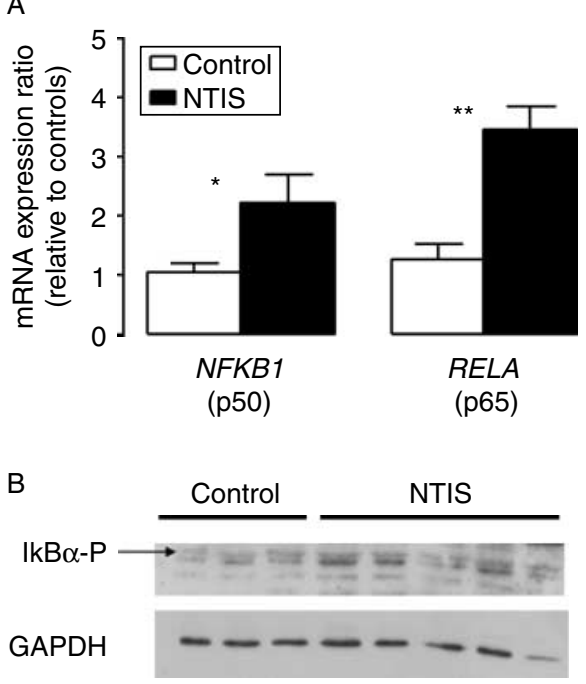

Figure 3 (A) mRNA expression of NFKB1 (p50) and RELA (p65), two major components of the NFKB1 pathway, was increased in SM biopsies from NTIS patients. (B) No differences in SM IkB $\alpha$ phosphorylation levels were observed between control and NTIS patients. ${ }^{\star} P<0.05,{ }^{\star \star} P<0.01$.

secondary to septic shock caused by Gram-negative bacteria shows a decrease in the TH receptors, THRA and THRB1, as well as in RXRG (11). LPS plays a central role in the pathophysiology of septic shock caused by Gram-negative bacteria. LPS binds to Toll-like receptor 4 (TLR4), activating the NFKB1 pathway that in turn increases transcription of a range of genes associated with inflammation and immunity, thus causing a strong inflammatory response. TLR4 is present in SM (31), and LPS binding to TLR4 could therefore underlie the changes observed in the SM of patients with septic shock-associated NTIS; indeed, mice deficient in TLR4 do not develop NTIS in response to LPS, and bacterialrelated NTIS requires the activation of TLR-MyD88 pathway which leads to the production of inflammatory cytokines (32). However, the patients with non-septic shock NTIS also had decreased levels of TH receptors and RXRG mRNA, and protein expression in SM, suggesting that this pattern constitutes a common response of SM during NTIS.

TH promotes proteolysis and a shift from the more energetically efficient slow oxidative muscle fibers to fast glycolytic muscle fibers, increasing energy uncoupling and thus the expenditure of energy as heat. The decreases in TH receptor levels and RXRG mRNA could therefore comprise a mechanism to prevent energy expenditure as well as to protect proteins from being broken down (25) under situations of low SM activity. Interestingly, non-septic NTIS patients showed an increase in RXRA mRNA expression but a decrease in protein levels, suggesting the existence of a posttranscriptional abnormality in the synthesis or degradation of RXRA. Under catabolic conditions, there is an ubiquitin-proteasome-dependent protein degradation (33), and RXRA suffers post-translational regulation by ubiquitination resulting in its rapid degradation $(34,35)$. This mechanism could explain the decrease in RXRA protein levels in NTIS patients. TH receptor binding to MYH is increased by RXRA (36), so a decrease in both transcription factors could constitute a mechanism to prevent TH altering the SM phenotype. Moreover, a decrease in TH receptors, RXRA, and RXRG, would reduce uptake and oxidation of fatty acids by SM, an effect that could be counteracted, however, by an increase in PPARG transcriptional activity. The RXRA gene is highly expressed in SM suggesting an important regulatory role. In addition, proteasomal degradation of its protein product could affect PPARG activity as shown in obese human adipose tissue (35); PPARG action depends on its dimerization with different RXR isotypes, and a decrease in RXRA has been shown to increase transcriptional activity of PPARG (35). Finally, a decrease in RXRs could protect SM cells from apoptosis during the stressful conditions of NTIS (37).

Unexpectedly, no changes were observed in mRNA expression levels of the TH-responsive genes MYH1, MYH4, SERCA1, and SERCA, and the expression of UCP 3 and GLUT4, two genes up-regulated by TH, was higher in non-septic shock NTIS patients than in control patients. $\mathrm{T}_{3}$ content of SM biopsies was not measured due to the small amount of tissue available, although it is reasonable to assume that it was low in NTIS SM, since not only serum levels of $\mathrm{T}_{3}$ but also mRNA expression of

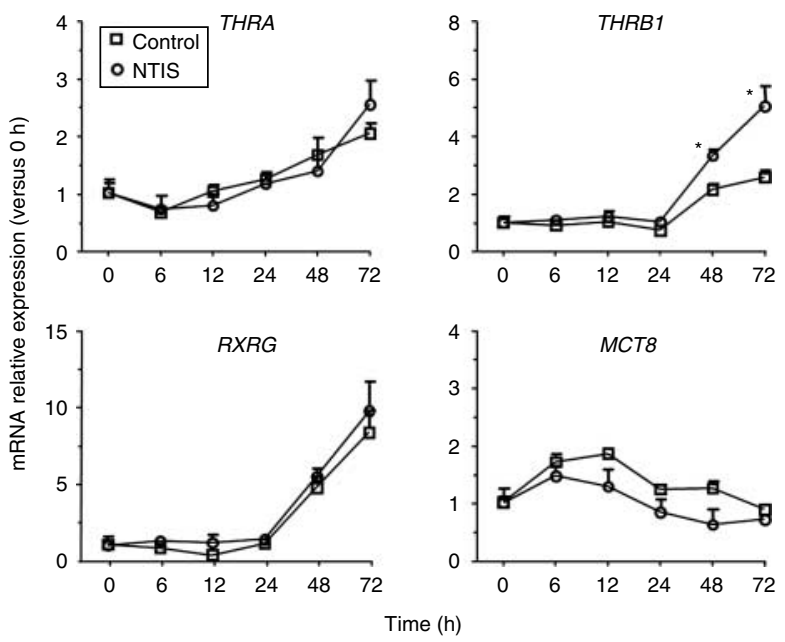

Figure 4 Cells from a primary human skeletal muscle cell line, HSkMC, were incubated for $72 \mathrm{~h}$ in serum from control or NTIS patients to evaluate changes in THRA, THRB1, RXRG, and MCT8 gene expression. THRA, THRB1, and RXRG expression did not change from 0 to $24 \mathrm{~h}$, but had increased significantly at 48 and $72 \mathrm{~h}$. No differences were observed between cells incubated in control or NTIS serum with respect to THRA and RXRG expression, but at 48 and $72 \mathrm{~h}$, THRB1 expression was significantly higher in cells incubated in serum from NTIS patients. By contrast, MCT8 expression had not increased at 48 and $72 \mathrm{~h}$ in either groups. ${ }^{\star} P<0.05$ NTIS versus controls. 
DIO2 was lower in non-septic shock NTIS SM than in control SM. In mice under TH deprivation, the response of TH positively regulated genes is variable, and some of these genes do not show basal repression (38). This has also been observed in NTIS patients in our study, although the mechanisms responsible for these changes are unknown. It is possible that the non-repressed genes recruit co-repressors weakly or not at all in the absence of $\mathrm{TH}$, or that the repressive effect of the unliganded $\mathrm{TH}$ receptors is overcome by the action of other transcription factors. UCP 3 gene transcription is up-regulated by TH through both THRA and THRB1 receptors; UCP 3 expression is also increased under circumstances where fatty acids are elevated likely during starvation (39), which is a cause of NTIS. Although not measured in the present study, the serum levels of fatty acids were probably elevated in ICU patients because they frequently receive i.v. heparin, and lipolysis is increased under severe stressful situations. TH increases GLUT4 expression in SM, causing an increase in basal and insulin-stimulated glucose transport $(40,41)$. GLUT4 mRNA expression is higher in slow oxidative muscle fibers than in fast glycolytic muscle fibers (42), due in part to a muscle-specific GLUT4 promoter enhancer that contributes to these differences (43). This enhancer contains three co-operative elements, a myocyte enhancer factor 2 (MEF2)-binding site, a low-affinity binding site for $\mathrm{TH}$ receptors, and a MyoD-binding site next to the MEF2 site (43). Interestingly, under normal conditions (non-damaged muscle), the thyroid response element-binding site blocks the promoter activity. The greater activity of the muscle-specific GLUT4 enhancer in oxidative muscles than in glycolytic muscles is a consequence of a greater activity of the MEF2-binding site (43). A decrease in $\mathrm{TH}$ and $\mathrm{TH}$ receptor expression levels could increase the activity of MEF2 and the ratio of oxidative to fast muscle fibers, explaining in part why NTIS patients showed higher GLUT4 expression levels than controls. A higher expression of SM MEF2 isoforms that operate in the enhancer could also contribute to the higher level of GLUT4 expression in NTIS patients. Overall, these unexpected changes seem to be the result of compensatory mechanisms that remain to be elucidated.

The NTIS patients have significantly increased serum levels of the pro-inflammatory cytokines IL6, IL8, IL2R, and TNF, which have been shown to decrease expression levels of THRA, THRB1, and RXRA in liver cells (19, 4446). Since pro-inflammatory cytokines activate NFKB1 pathway, we investigated whether NFKB1 was activated in SM from patients with non-septic shock NTIS. The NFKB1 family is composed of five members that include NFKB1 or p50 and RELA or p65 subunits that are responsible for many of the actions of NFKB1. NFKB1 members form heterodimers that are sequestered into the cytoplasm bound to nuclear factor of kappa light polypeptide gene enhancer in B-cell inhibitors or IkB proteins that inhibit dimer migration to the nucleus; p50-p65 dimers are retained in the cytoplasm by IkB $\alpha$. NFKB1 is activated in response to a variety of stimuli that bind to the TLR4; the classical NFKB1 pathway is activated by cytokines and bacterial LPS through activation of inhibitory $\mathrm{kB}$ kinases (IKKs). IKKs phosphorylate $\mathrm{IkB} \alpha$ at serines 32 and 36, causing the release of p50-p65 heterodimers that are free to migrate to the nucleus where they regulate gene transcription. NFKB1 (p50) and RELA (p65) mRNA expression levels were increased in non-septic shock NTIS SM, suggesting that the classical NFKB1 pathway might have been activated. Phosphorylation-based signal transduction is often transient, but an increased steady-state level of $\mathrm{IkB} \alpha$ phosphorylation has been reported under several conditions that activate the NFKB1 pathway in lymphocytes from hyperthyroid rats (47), acute lymphoblastic leukemia cells (48), or melanoma cells (49). No differences were observed in $\operatorname{IkB} \alpha$ phosphorylation levels between non-septic shock NTIS and control patients, indicating that the SM of patients with NTIS did not have a more highly activated NFKB1 pathway. Thus, the changes observed in gene and protein expression between the two groups could not be attributed to changes in activation of the NFKB1 pathway.

HSkMCs incubated in serum from patients with NTIS did not show decreased mRNA expression of MCT8, THRB1, THRA, or RXRG. Indeed, not only the expression of $\mathrm{TH}$ receptors but also the expression of $R X R G$ increased in cells incubated either in serum obtained from NTIS patients or in serum obtained from control patients; THRB1 expression was higher in cells incubated in NTIS serum than in control serum at 48 and $72 \mathrm{~h}$. These unexpected results might be attributed to the fact that cells were incubated in $20 \%$ serum that has lower concentration of ILs than 100\% serum. On the other hand, the fact that THRB1 expression increased in cells incubated in NTIS serum argues against the presence of inhibitory factors in serum in vivo being responsible for changes observed in patients. Patients with critical illness may have an over-activated sympathetic nervous system that can lead to adverse consequences (50); however, the likely role of a sympathetic nervous system response in the pathophysiology of NTIS remains unknown.

In conclusion, SM from patients with non-septic shock NTIS showed decreased gene and protein expression levels of $\mathrm{TH}$ receptors and RXRs. The decrease in $\mathrm{TH}$ receptors did not significantly affect the expression of genes important to SM physiology. No differences in $\mathrm{IkB} \alpha$ phosphorylation were observed in the SM of NTIS and control patients, suggesting that activation of the classical NFKB1 pathway seems to be not responsible for the decreases found in $\mathrm{TH}$ receptor and RXR expression levels. Finally, TH receptor and RXRs expression in primary cultures of HSkMCs did not decrease when exposed to serum from NTIS patients, 
suggesting that the changes observed in vivo could be mediated by serum-independent factors or mechanisms.

\section{Declaration of interest}

The authors declare that there is no conflict of interest that could be perceived as prejudicing the impartiality of the research reported.

\section{Funding}

This study was supported by the Spanish Ministerio de Educación (SAF2006-02542 to J Lado-Abeal) and by Xunta de Galicia (PGIDIT04PXIC20801PN and PGIDIT06PXIB 208360PR to J LadoAbeal).

\section{Author contribution statement}

J Lado-Abeal conceived the study, participated in its design and coordination, got the research funds, and wrote the manuscript. A Romero carried out the gene and protein expression analyses and the cell culture studies. I Castro-Piedras carried out the NFKB1 studies. A Rodriguez-Perez and J Alvarez-Escudero participated in the study design, selected the patients, got the consents, and performed the biochemical analyses and the muscle biopsies.

\section{References}

1 Wartofsky L \& Burman KD. Alterations in thyroid function in patients with systemic illness: the 'euthyroid sick syndrome'. Endocrine Reviews 19823 164-217. (doi:10.1210/edrv-3-2-164)

2 Peeters RP, van der Geyten S, Wouters PJ, Darras VM, van Toor H, Kaptein E, Visser TJ \& Van den Berghe G. Tissue thyroid hormone levels in critical illness. Journal of Clinical Endocrinology and Metabolism 200590 6498-6507. (doi:10.1210/jc.2005-1013)

3 De Groot LJ. Dangerous dogmas in medicine: the nonthyroidal illness syndrome. Journal of Clinical Endocrinology and Metabolism 199984 151-164. (doi:10.1210/jc.84.1.151)

4 Stathatos N, Levetan C, Burman KD \& Wartofsky L. The controversy of the treatment of critically ill patients with thyroid hormone. Best Practice \& Research. Clinical Endocrinology \& Metabolism 200115 465-478. (doi:10.1053/beem.2001.0164)

5 Stathatos N\& Wartofsky L. The euthyroid sick syndrome: is there a physiological rationale for thyroid hormone treatment? Journal of Endocrinological Investigation 200326 1174-1179.

6 De Groot LJ. Non-thyroidal illness syndrome is a manifestation of hypothalamic-pituitary dysfunction, and in view of current evidence, should be treated with appropriate replacement therapies. Critical Care Clinics 200622 57-86. (doi:10.1016/j. ccc.2005.10.001)

7 Fliers E, Guldenaar SE, Wiersinga WM \& Swaab DF. Decreased hypothalamic thyrotropin-releasing hormone gene expression in patients with nonthyroidal illness. Journal of Clinical Endocrinology and Metabolism 199782 4032-4036. (doi:10.1210/jc.82.12. 4032)

8 Van den Berghe G, de Zegher F, Baxter RC, Veldhuis JD, Wouters P, Schetz M, Verwaest C, Van der Vorst E, Lauwers P, Bouillon R \& Bowers CY. Neuroendocrinology of prolonged critical illness: effects of exogenous thyrotropin-releasing hormone and its combination with growth hormone secretagogues. Journal of Clinical Endocrinology and Metabolism $1998 \mathbf{8 3} 309-319$. (doi:10.1210/jc.83. 2.309)

9 Maia AL, Kim BW, Huang SA, Harney JW \& Larsen PR. Type 2 iodothyronine deiodinase is the major source of plasma $\mathrm{T}_{3}$ in euthyroid humans. Journal of Clinical Investigation 2005115 2524-2533. (doi:10.1172/JCI25083)

10 Peeters RP, Wouters PJ, Kaptein E, van Toor H, Visser TJ \& Van den Berghe G. Reduced activation and increased inactivation of thyroid hormone in tissues of critically ill patients. Journal of Clinical Endocrinology and Metabolism 200388 3202-3211. (doi:10.1210/jc.2002-022013)

11 Rodriguez-Perez A, Palos-Paz F, Kaptein E, Visser TJ, DominguezGerpe L, Alvarez-Escudero J \& Lado-Abeal J. Identification of molecular mechanisms related to non-thyroidal illness syndrome in skeletal muscle and adipose tissue from patients with septic shock. Clinical Endocrinology 200868 821-827. (doi:10.1111/j. 1365-2265.2007.03102.x)

12 Arem R, Wiener GJ, Kaplan SG, Kim HS, Reichlin S \& Kaplan MM. Reduced tissue thyroid hormone levels in fatal illness. Metabolism 199342 1102-1108. (doi:10.1016/0026-0495(93)90266-Q)

13 Hennemann G, Docter R, Friesema EC, de Jong M, Krenning EP \& Visser TJ. Plasma membrane transport of thyroid hormones and its role in thyroid hormone metabolism and bioavailability. Endocrine Reviews 200122 451-476. (doi:10.1210/er.22.4.451)

14 Bartalena L, Bogazzi F, Brogioni S, Grasso L \& Martino E. Role of cytokines in the pathogenesis of the euthyroid sick syndrome. European Journal of Endocrinology 1998138 603-614. (doi:10. 1530/eje.0.1380603)

15 Lee HY, Suhl J, Pekary AE \& Hershman JM. Secretion of thyrotropin with reduced concanavalin-A-binding activity in patients with severe nonthyroid illness. Journal of Clinical Endocrinology and Metabolism 198765 942-945. (doi:10.1210/ jcem-65-5-942)

16 De Jongh FE, Jöbsis AC \& Elte JW. Thyroid morphology in lethal non-thyroidal illness: a post-mortem study. European Journal of Endocrinology 2001144 221-226. (doi:10.1530/eje.0.1440221)

17 Langton JE \& Brent GA. Nonthyroidal illness syndrome: evaluation of thyroid function in sick patients. Endocrinology and Metabolism Clinics of North America 200231 159-172. (doi:10. 1016/S0889-8529(01)00008-1)

18 Nagaya T, Fujieda M, Otsuka G, Yang JP, Okamoto T \& Seo H. A potential role of activated NF- $\mathrm{KB}$ in the pathogenesis of euthyroid sick syndrome. Journal of Clinical Investigation $2000 \mathbf{1 0 6}$ 393-402. (doi:10.1172/JCI7771)

19 Kwakkel J, Wiersinga WM \& Boelen A. Differential involvement of nuclear factor-kappaB and activator protein-1 pathways in the interleukin-1ß-mediated decrease of deiodinase type 1 and thyroid hormone receptor B1 mRNA. Journal of Endocrinology 2006189 37-44. (doi:10.1677/joe.1.06354)

20 Zurlo F, Larson K, Bogardus C \& Ravussin E. Skeletal muscle metabolism is a major determinant of resting energy expenditure. Journal of Clinical Investigation 199086 1423-1427. (doi:10. 1172/JCI114857)

21 Visser WE, Heemstra KA, Swagemakers SM, Ozgür Z, Corssmit EP, Burggraaf J, van Ijcken WF, van der Spek PJ, Smit JW \& Visser TJ. Physiological thyroid hormone levels regulate numerous skeletal muscle transcripts. Journal of Clinical Endocrinology and Metabolism 200994 3487-3496. (doi:10.1210/jc.2009-0782)

22 Simonides WS \& van Hardeveld C. Thyroid hormone as a determinant of metabolic and contractile phenotype of skeletal muscle. Thyroid 200818 205-216. (doi:10.1089/thy.2007. 0256)

23 Simonides WS, Thelen MH, van der Linden CG, Muller A \& van Hardeveld C. Mechanism of thyroid-hormone regulated expression of the SERCA genes in skeletal muscle: implications for thermogenesis. Bioscience Reports 200121 139-154. (doi:10. 1023/A:1013692023449)

24 de Lange P, Senese R, Cioffi F, Moreno M, Lombardi A, Silvestri E, Goglia F \& Lanni A. Rapid activation by 3,5,3'-L-triiodothyronine of adenosine $5^{\prime}$-monophosphate-activated protein kinase/acetylcoenzyme A carboxylase and Akt/protein kinase B signaling pathways: relation to changes in fuel metabolism and myosin heavy-chain protein content in rat gastrocnemius muscle in vivo. Endocrinology 2008149 6462-6470. (doi:10.1210/en.20080202)

25 Brennan MD, Coenen-Schmke JM, Bigelow ML \& Nair KS. Changes in skeletal muscle protein metabolism and myosin heavy chain 
isoform messenger ribonucleic acid abundance after treatment of hyperthyroidism. Journal of Clinical Endocrinology and Metabolism 200691 4650-4656. (doi:10.1210/jc.2006-1074)

26 Lu B, Moser AH, Shigenaga JK, Feingold KR \& Grunfeld C. Type II nuclear hormone receptors, coactivator, and target gene repression in adipose tissue in the acute-phase response. Journal of Lipid Research $2006 \quad 47$ 2179-2190. (doi:10.1194/jlr.M500540JLR200)

27 Ying H, Araki O, Furuya F, Kato Y \& Cheng SY. Impaired adipogenesis caused by a mutated thyroid hormone alpha1 receptor. Molecular and Cellular Biology 200727 2359-2371. (doi:10.1128/MCB.02189-06)

28 Sutanto MM, Ferguson KK, Sakuma H, Ye H, Brady MJ \& Cohen RN. The silencing mediator of retinoid and thyroid hormone receptors (SMRT) regulates adipose tissue accumulation and adipocyte insulin sensitivity in vivo. Journal of Biological Chemistry 2010285 18485-18495. (doi:10.1074/jbc.M110. 107680)

29 Livak KJ \& Schmittgen TD. Analysis of relative gene expression data using real-time quantitative PCR and the $2^{-\Delta \Delta C_{\mathrm{t}}}$ method. Methods 200125 402-408. (doi:10.1006/meth.2001.1262)

30 Lado-Abeal J \& Castro-Piedras I. Nonthyroidal illness syndrome. Hot Thyroidology, 2009 11/09.

31 Lang CH, Silvis C, Deshpande N, Nystrom G \& Frost RA. Endotoxin stimulates in vivo expression of inflammatory cytokines tumor necrosis factor alpha, interleukin-1beta, -6 , and high-mobilitygroup protein-1 in skeletal muscle. Shock 200319 538-546. (doi:10.1097/01.shk.0000055237.25446.80)

32 Rocchi R, Kimura H, Tzou SC, Suzuki K, Rose NR, Pinchera A, Ladenson PW \& Caturegli P. Toll-like receptor-MyD88 and FC receptor pathways of mast cells mediate the thyroid dysfunctions observed during nonthyroidal illness. PNAS $2007 \mathbf{1 0 4}$ 6019-6024. (doi:10.1073/pnas.0701319104)

33 Hasselgren PO, Wray C \& Mammen J. Molecular regulation of muscle cachexia: it may be more than the proteasome. Biochemical and Biophysical Research Communications 2002290 1-10. (doi:10. 1006/bbrc.2001.5849)

34 Adachi S, Okuno M, Matsushima-Nishiwaki R, Takano Y, Kojima S, Friedman SL, Moriwaki H \& Okano Y. Phosphorylation of retinoid $X$ receptor suppresses its ubiquitination in human hepatocellular carcinoma. Hepatology 200235 332-340. (doi:10. 1053/jhep.2002.31164)

35 Lefebvre B, Benomar Y, Guédin A, Langlois A, Hennuyer N, Dumont J, Bouchaert E, Dacquet C, Pénicaud L, Casteilla L, Pattou F, Ktorza A, Staels B \& Lefebvre P. Proteasomal degradation of retinoid $X$ receptor alpha reprograms transcriptional activity of PPARgamma in obese mice and humans. Journal of Clinical Investigation 2010120 1454-1468. (doi:10.1172/JCI38606)

36 Muscat GEO, Griggs R, Downes M \& Emery J. Characterization of the thyroid hormone receptor element in skeletal $\alpha$-actin gene: negative regulation of $\mathrm{T}_{3}$ receptor binding by the retinoid $\mathrm{X}$ receptor. Cell Growth \& Differentiation 19934 269-279.

37 Szanto A, Narkar V, Shen Q, Uray IP, Davies PJA \& Nagy L. Retinoid X receptors: X-ploring their (patho)physiological functions. Cell Death and Differentiation 200411 S126-S143. (doi:10. 1038/sj.cdd.4401533)

38 Yen PM, Feng X, Flamant F, Chen Y, Walker RL, Weiss RE, Chassande O, Samarut J, Refetoff S \& Meltzer PS. Effects of ligand and thyroid hormone receptor isoforms on hepatic gene expression profiles of thyroid hormone receptor knockout mice. EMBO Reports 20034 4 581-587. (doi:10.1038/sj.embor. embor862)
39 Solanes G, Pedraza N, Calvo V, Vidal-Puig A, Lowell BB \& Villarroya F. Thyroid hormones directly activate the expression of the human and mouse uncoupling protein-3 genes through a thyroid response element in the proximal promoter region. Biochemical Journal $2005 \mathbf{3 8 6}$ 505-513. (doi:10.1042/ BJ20041073)

40 Weinstein SP, O'Boyle E \& Haber RS. Thyroid hormone increases basal and insulin-stimulated glucose transport in skeletal muscle. The role of GLUT4 glucose transporter expression. Diabetes 1994 43 1185-1189. (doi:10.2337/diabetes.43.10.1185)

41 Torrance CJ, Devente JE, Jones JP \& Dohm GL. Effects of thyroid hormone on GLUT4 glucose transporter gene expression and NIDDM in rats. Endocrinology 1997138 1204-1214. (doi:10. 1210/en.138.3.1204)

42 Kern M, Wells JA, Stephens JM, Elton CW, Friedman JE, Tapscott EB, Pekala PH \& Dohm GL. Insulin responsiveness in skeletal muscle is determined by glucose transporter (Glut4) protein level. Biochemical Journal 1990270 397-400.

43 Moreno H, Serrano AL, Santalucía T, Gumá A, Cantó C, Brand NJ, Palacin M, Schiaffino S \& Zorzano A. Differential regulation of the muscle-specific GLUT4 enhancer in regenerating and adult skeletal muscle. Journal of Biological Chemistry $2003 \mathbf{2 7 8}$ 40557-40564. (doi:10.1074/jbc.M306609200)

44 Kwakkel J, Wiersinga WM \& Boelen A. Interleukin-1beta modulates endogenous thyroid hormone receptor alpha gene transcription in liver cells. Journal of Endocrinology $2007 \mathbf{1 9 4}$ 257-265. (doi:10.1677/JOE-06-0177)

45 Geier A, Dietrich CG, Voigt S, Ananthanarayanan M, Lammert F, Schmitz A, Trauner M, Wasmuth HE, Boraschi D, Balasubramaniyan N, Suchy FJ, Matern S \& Gartung C. Cytokine-dependent regulation of hepatic organic anion transporter gene transactivators in mouse liver. American Journal of Physiology. Gastrointestinal and Liver Physiology $2005 \mathbf{2 8 9}$ G831-G841. (doi:10.1152/ajpgi.00307.2004)

46 Kim MS, Sweeney TR, Shigenaga JK, Chui LG, Moser A, Grunfeld C $\&$ Feingold KR. Tumor necrosis factor and interleukin 1 decrease RXRalpha, PPARalpha, PPARgamma, LXRalpha, and the coactivators SRC-1, PGC-1alpha, and PGC-1beta in liver cells. Metabolism 200756 267-279. (doi:10.1016/j.metabol.2006. 10.007)

47 Vinayagamoorthi R, Koner BC, Kavitha S, Nandakumar DN, Padma Priya P \& Goswami K. Potentiation of humoral immune response and activation of NF-kappaB pathway in lymphocytes in experimentally induced hyperthyroid rats. Cellular Immunology 2005238 56-60. (doi:10.1016/j.cellimm.2006.01.002)

48 Kordes U, Krappmann D, Heissmeyer V, Ludwig WD \& Scheidereit C. Transcription factor NF-kappaB is constitutively activated in acute lymphoblastic leukemia cells. Leukemia 2000 14 399-402. (doi:10.1038/sj.leu.2401705)

49 Devalaraja MN, Wang DZ, Ballard DW \& Richmond A. Elevated constitutive IkappaB kinase activity and IkappaB-alpha phosphorylation in Hs294T melanoma cells lead to increased basal MGSA/GRO-alpha transcription. Cancer Research 199959 1372-1377.

50 Dunser MW \& Hasibeder WR. Sympathetic overstimulation during critical illness: adverse effects of adrenergic stress. Journal of Intensive Care Medicine $2009 \quad \mathbf{2 4}$ 293-316. (doi:10.1177/ 0885066609340519)

Received 6 August 2010

Accepted 24 August 2010 